\title{
Sorgum (Sorghum bicolor L.)'da sülfat taşıyıcı (SULTR) genlerin kuraklık stresi altında ifadelerinin belirlenmesi
}

\author{
Expression profiles of sorghum (Sorghum bicolor L.) SULTR genes under drought \\ stress
}

\section{Aydın AKBUDAK}

Akdeniz Üniversitesi, Ziraat Fakültesi, Tarımsal Biyoteknoloji Bölümü, Antalya

Sorumlu yazar (Corresponding author): M. A. Akbudak, e-posta (e-mail): akbudak@akdeniz.edu.tr

\section{MAKALE BILGİSİ}

Alınıs tarihi 09 Subat 2018

Düzeltilme tarihi 07 Mart 2018

Kabul tarihi 07 Mart 2018

\section{Anahtar Kelimeler:}

Sorgum

Kuraklık

Sülfat

SULTR genleri

Gen ifadesi

\begin{abstract}
Öz
Küresel isınmadan kaynaklanan iklim değișikleri nedeniyle kuraklık, özellikle son 20 yılda tarımsal üretimi kısıtlayan en önemli problem haline gelmiştir. Bitkilerin su yetersizliği şartlarına uyum sağlamalarına imkân sağlayacak mekanizmaların anlaşılması, kuraklık nedeniyle meydana gelen verim kayıplarına çözüm bulunması için oldukça önemlidir. Kükürt ve kükürt içeren bileşikler, bitkilerin kuraklık dâhil pek çok stres koşuluyla mücadele etmesinde çeșitli fonksiyonlara sahiptirler. Arabidopsis thaliana' da 12 adet sülfat $\left(\mathrm{SO}_{4}{ }^{-2}\right)$ taşıyıcı (SULTR) gen tanımlanmış olup, bu genler kodladıkları proteinlerin aminoasit dizilerindeki benzerlikler göz önüne alınarak dört gruba ayrılmışlardır. SULTR proteinleri bitkilerde sülfatın topraktan alınmasında ve bitki içerisinde tașınmasında ceșitli görevler üstlenmektedirler. Bu çalışmada sorgum (Sorghum bicolor L.) SULTR genlerinin (SbSULTR) kuraklık şartlarındaki ifadeleri incelenmiștir. Yapılan gen ifade analizleri, kuraklık stres altında yapraklarda beş, köklerde ise altı SbSULTR geninin ifadesindeki artışa karşın, yapraklarda üç, köklerde ise iki SbSULTR geninin ifadesinin azaldığını göstermiştir SbSULTR4 geninin yapraklardaki ifadesinde yaklaşık yedi katlık bir artış tespit edilmiştir. Elde edilen sonuçlar, kuraklık koşulları altında SbSULTR genlerinin ifadesinin büyük çoğunlukla arttığına ve sülfür içeren bileşiklerin sorgumun kuraklık ile mücadelesinde görev aldığına işaret etmektedir.
\end{abstract}

\section{ARTICLE INFO}

Received 09 February 2018

Received in revised form 07 March 2018 Accepted 07 March 2018

\section{Keywords:}

Sorghum

Drought

Sulfate

SULTR genes

Gene expression

\begin{abstract}
Due to climate changes arising from global warming, drought has become a major problem restricting agricultural production for the last 20 years. Understanding mechanisms that help plants to get adjusted water deficiency is important to come up with yield loss on account of drought. Sulfur and sulfur-containing compounds have significant roles in plants to fight with several stress conditions including drought. Twelve sulfate transporter (SULTR) genes were initially identified in Arabidopsis thaliana and subdivided into four groups based on their protein sequence similarities. SULTR proteins have various functions in plants including sulfate uptake from soil and transportation of sulfate in plants. Expression profiles of SbSULTR genes in sorghum under drought condition were investigated in this study. Gene expression analyses showed that five SbSULTR genes in leaves and six in roots were upregulated while three $S b S U L T R$ genes in leaves and two genes in roots were down-regulated. Approximately, seven fold up-regulation was detected in SbSULTR4 in leaves. Consequently, results revealed that SULTR genes were mainly up-regulated under drought conditions, and sulfur containing compounds got employed in sorghum to battle drought.
\end{abstract}

\section{Giriş}

Kuraklık tarımsal üretimi etkileyen en önemli abiyotik strestir. Küresel 1sınmadaki artışa paralel olarak daha da sık bir şekilde meydana gelmesi beklenen iklim değişiklikleri nedeniyle, sürdürülebilir tarımın önünde acil olarak çözülmesi gereken bir sorun olarak durmaktadır. Kuraklık kaynaklı ürün kayıplarıyla mücadele edebilmek için bitkilerin su sıkıntısına uyum sağlamalarına imkân veren mekanizmaların anlaşılması büyük bir önem arz etmektedir.

Elementel kükürt (S) ve kükürt içeren bileşikler (hidrojen sülfit, glutatyon, fitoşelatin vb.) bitkilerin kuraklık kaynaklı stres koşullarıyla mücadele etmesinde çeşitli görevler almaktadırlar. Kükürt bitkiler tarafından topraktan sülfat 
$\left(\mathrm{SO}_{4}{ }^{-2}\right)$ formunda alınmakta olup, önce sülfide $\left(\mathrm{S}^{-2}\right)$ indirgenmekte daha sonra $O A S T L$ genleri aracılığıyla sisteine (Cys) dönüştürülmektedir. Çocuklar, yaşlılar ve bazı metabolik rahatsızlıkları olan bireyler için esansiyel bir aminoasit olan sistein ise bitkilerde proteinlerin, vitaminlerin, etilen ve bazı kofaktörlerin yapısına girmektedir (Capaldi ve ark. 2015). Bitki hormonları, değişen çevre şartları ve stres koşullarına karşı bitkilerin adaptasyonu için hayati fonksiyonlara sahip olup, görev aldıkları iletim yolaklarını, su ve besin maddelerinin etkin kullanımını, bitkinin gelişim aşamalarını ve metabolizmasını kontrol etmektedirler (Peleg ve Blumwald 2011; Fatma ve ark. 2013). Bitki hormonları ve sülfat asimilasyonu arasında güçlü ve önemli bir ilişki mevcuttur (Maruyama-Nakashita ve ark. 2004; 2005; Kopriva 2006).

Yapılan çalışmalar kuraklık durumunda stoma iletkenliğini kontrol eden ana düzenleyici olan absisik asit (ABA) ile sülfatın yakın ilişkisi olduğunu göstermektedir (Wilkinson ve Davies 2002). Ernst ve ark. (2010) ABA'nın stomalara ulaşarak buharlaşmayı önleyici etkisini göstermesinde sülfatın ana sinyal olduğunu ileri sürmüşlerdir.

Çevresel stres koşulları, bitkilerde neden oldukları reaktif oksijen türlerinin (ROS) üretimindeki artış ve sonucunda meydana gelen oksidatif stres nedeniyle genellikle bitki gelişimini olumsuz etkilemektedirler (Boaretto 2014). Artan bu reaktif oksijen türlerinin detoksifikasyon yoluyla hücreye zarar vermesinin önlenmesi ve bozulan redoks dengesinin kurulmas için stres koşulları altında bitki savunma sisteminde yer alan glutatyon, kükürtlü aminoasitler (sistein ve metionin), kükürtçe zengin proteinler, hidrojen sülfit $\left(\mathrm{H}_{2} \mathrm{~S}\right)$, metallothioneinler ve fitoşelatinler gibi kükürtlü bileşiklerin fonksiyonları ve miktarlarında artış görülmektedir (Noctor 2006; Choudhury ve ark. 2013).

Sülfatın bitkiler tarafından topraktan alınması, bitki içerisinde dağıtılması ya da vakuolden sülfatın dışarı çıkarılmasında görev alan SULTR genlerinin saptanması ve tanımlanmasına yönelik çeşitli çalışmalar mevcuttur (Buchner ve ark. 2004). Bitkilerde bugüne kadar yaklaşık 12-16 adet SULTR kodlayan gen tanımlanmış olup, SULTR proteinlerinin amino asit dizi benzerlikleri göz önünde bulundurularak bu genler dört gruba ayrılmıştır (SULTR 1-4) (Davidian ve Kopriva 2010; Cao ve ark. 2013). Bu taşıyıcılardan köklerde sentezlenen, SULTR1;1 ve SULTR1;2'nin sülfata ilgisi yüksek olup, topraktaki $S$ miktarının azalması durumunda sülfatı bitki köklerine taşımakta ve alımını sağlamaktadırlar (Takahashi ve ark. 2012). SULTR 2;1 ve SULTR2;2 ise sülfatın köklerden sürgünlere taşınmasında görev almaktadır. SULTR1 grubuna ait olan, SULTR1;3 floemde lokalize olmuştur ve yine sülfatın sürgünlerden köklere taşınmasında görev alır. SULTR3;1, SULTR3;2 ve SULTR3;3 yapraklarda sentezlenmekte olup sülfür asimilasyonunda görev almaktadır. Sülfatın bitki hücrelerindeki ana depolanma bölgesi vakuoldür. SULTR4; 1 ve SULTR4;2 tonoplastların zarlarında lokalizedir ve hücre içerisinde kullanılmak üzere sülfatın vakuolden sitoplazmaya geçişinde rol almaktadır (Cao ve ark. 2013).

Sülfat taşıyıcıların abiyotik streslerle mücadeledeki görevleri konusunda yapılan çalışmalar oldukça yeni ve sınırlı sayida olup (Cao ve ark. 2013; Tombuloglu ve ark. 2017; Akbudak ve ark. 2018) bu konuda yapılacak yeni çalışmalar sülfür ve sülfür içeren bileşiklerin stres koşulları altında bitki savunma mekanizmasındaki görevlerinin aydınlatılmasında faydalı olacaktır. $\mathrm{Bu}$ çalışmada Sorghum bicolor'da tanımlanmış 9 adet SULTR geninin (Akbudak ve ark. 2018) kuraklık stresi altında ifade profilleri ortaya konulmuştur.

\section{Materyal ve Yöntem}

\subsection{Bitki materyali ve büyütme koşulları}

Çalışmada kullanılan Öğretmenoğlu 77 çeşidine ait sorgum (S. bicolor L.) tohumları Batı Akdeniz Tarımsal Araştırma Enstitüsü'nden temin edilmiştir. Tohumlar $10 \mathrm{~cm}^{2}$ büyüklüğünde torf içeren kaplara ekildikten sonra bitki büyütme kabininde büyütülmüşlerdir. Bitki büyütme kabinindeki sıcaklık $28^{\circ} \mathrm{C}$ ve 1 şı rejimi 12 saat gece, 12 saat gündüz olacak şekilde ayarlanmıştır. Bitkiler $30 \mathrm{ml}$ şebeke suyu ile günaşırı sulanmıştır. Ekimden 14 gün sonra kontrol bitkileri sulanmaya devam edilirken, deneme bitkilerine su verilmemiştir. Fenotipik gözlemler hem kontrol hem de deneme bitkileri için günlük olarak yapılmıştır. Deneme bitkilerinde su stresi ile ilgili fenotipik değişikliklerin görülmeye başlamasını müteakip (sulama kesildikten 10 gün sonra) tüm bitkilerin yaprakları ve kökleri hasat edilerek RNA izolasyonunda kullanılmıştır.

\subsection{RNA izolasyonu ve gen ifade analizleri}

RNA izolasyonu her bitkinin kök ve yapraklarından RNA Plant Mini Kit (Qiagen) yardımıyla üreticinin protokolü takip edilerek yapılmıştır. Örneklerdeki RNA miktarı Biodrop $\mu$ LITE (Biodrop, İngiltere) kullanılarak belirlenmiştir. DNA bulaşıklığını gidermek için örnekler RQ1 RNase-Free DNase (Promega, ABD) ile muamele edilmiştir. RNA örneklerinin kalitesini ve DNA bulaşıklığının devam edip etmediğini görmek üzere 500 ng RNA örneği \% 1'lik agaroz jel üzerinde elektroforez yöntemiyle yürütülmüştür. Real Time-quantitative PCR (RT-qPCR) analizleri Light Cycler 96 (Roche) ile yapılmıştır. SULTR genlerinin ifadeleri DNase muamelesi görmüş 10 ng RNA ile SuperScript III Platinium SYBR Green One-Step qRT-PCR Kit (Invitrogen) kullanılarak ölçülmüştür. RT-qPCR analizlerinde kullanılan primerler Primer 3 Input programı (http://bioinfo.ut.ee/primer3-0.4.0/) yardımıla tasarlanmış ve Macrogen (Amsterdam, Hollanda) tarafindan sentezlenmiştir (Tablo 1).

Gen ifade analizlerinde $\Delta \Delta C_{T}$ metodu (Livak ve Schmitthgen 2001) kullanılmıştır. Serin/threonin - protein fostafaz (PP2A) geni analizlerde referans gen olarak kullanılmıştır (Reddy 2016). Gen ifade analizleri için referans genin (PP2A) $C_{T}$ değerleri hedef genlerin (SULTR) $C_{T}$ değerlerinden çıkarılarak değerler normalize edilmiştir. Örneğin;

$$
\Delta C_{T}=C_{T}(\mathrm{SULTR})-C_{T}(\mathrm{PP} 2 \mathrm{~A})
$$

$\Delta \Delta C_{T}$ değerleri ise kuraklık stresi uygulanmış bitkilerin $\Delta C_{T}$ değerlerinin kontrol bitkilerinin $\Delta C_{T}$ değerlerinden çıkarılmasıyla elde edilmiştir. .

$$
\Delta \Delta C_{T}=\Delta C_{T} \text { (Kuraklık uygulanmış bitki) }-\Delta C_{T} \text { (Kontrol) }
$$

Her bir bitki için gen ifadesinin kaç kat arttığı ya da azaldı $\breve{g}_{1}$ ise aşağıda verilen eşitlik kullanılarak belirlenmiştir.

Değişim $=2^{-(\triangle \Delta C T)}$

Kök ve yaprakların ortalama $C_{T}$ değerleri her bir gen için en az üç teknik ve üç biyolojik tekrarlı verilerden elde edilmiştir.

\section{Sonuçlar ve Tartışma}

Kuraklık stresine maruz bırakılmış bitkilerde yapılan morfolojik gözlemlerde bitki büyümesinde gerileme, bitki gövdesinde ve yapraklarda incelme gözlemlenmiştir (Şekil 1). $\mathrm{Bu}$ gerilemeler, kuraklık stresine maruz kalan bitkilerin 
Tablo 1. SULTR genlerinin RT-qPCR analizleri için kullanılan primerler.

Table 1. Primers used for RT-qPCR analysis of SULTR genes.

\begin{tabular}{|c|c|c|c|}
\hline Genler & Forward primer sekansları & Reverse primer sekansları & PCR ürünü (bp) \\
\hline SbSULTR1;3 & 5'-AAGGGTGACTTCATCGCTGG-3' & 5'-TGTACTCAAGCGGGTGTGTC-3' & 244 \\
\hline SbSULTR2;1 & 5'-TCTCCAGAACGGCAGTGAAC-3' & 5'-CСААТСТССАCCGACCCAAA-3' & 268 \\
\hline SbSULTR2;2 & 5'-GGATGGCAGGTGATCCACAA-3' & 5'-TTCGCCAACCGTCAGAAAGA-3' & 81 \\
\hline SbSULTR3;1 & 5'-CAGGCTGGGGACATTCAAGT-3' & 5'-AGTCCACGATGAACCCCAAC-3' & 344 \\
\hline SbSULTR3;2 & 5'-CTTGATAGGTGCTGGGTGGT-3' & 5'-GTAGTCCCGTGCCTTCCATA-3' & 207 \\
\hline SbSULTR3;3 & 5'-TCATAGGGGAGGAGTGGGTG-3' & 5'-AAAAGATCTCTGTAGCGCGT-3' & 77 \\
\hline SbSULTR3;4 & 5'-TGGCACTGACTGTGATGGTC-3' & 5'-GCCAAGATCAAGAACCCGGA-3' & 364 \\
\hline SbSULTR3;5 & 5'-ATCATGAGCCAGATGAGGCG-3' & 5'-GGTCCTGCCCCAATCAAAGA-3' & 257 \\
\hline SbSULTR4 & 5'-GTGGAAATCCCCCAGCATCA-3' & 5'-AAGGTGAGCATGTTCGCTGA-3' & 78 \\
\hline $\operatorname{SbPP2A}$ & 5'-AACCCGCAAAACCCCAGACTA-3' & 5'TACAGGTCGGGCTCATGGAAC-3' & 138 \\
\hline
\end{tabular}

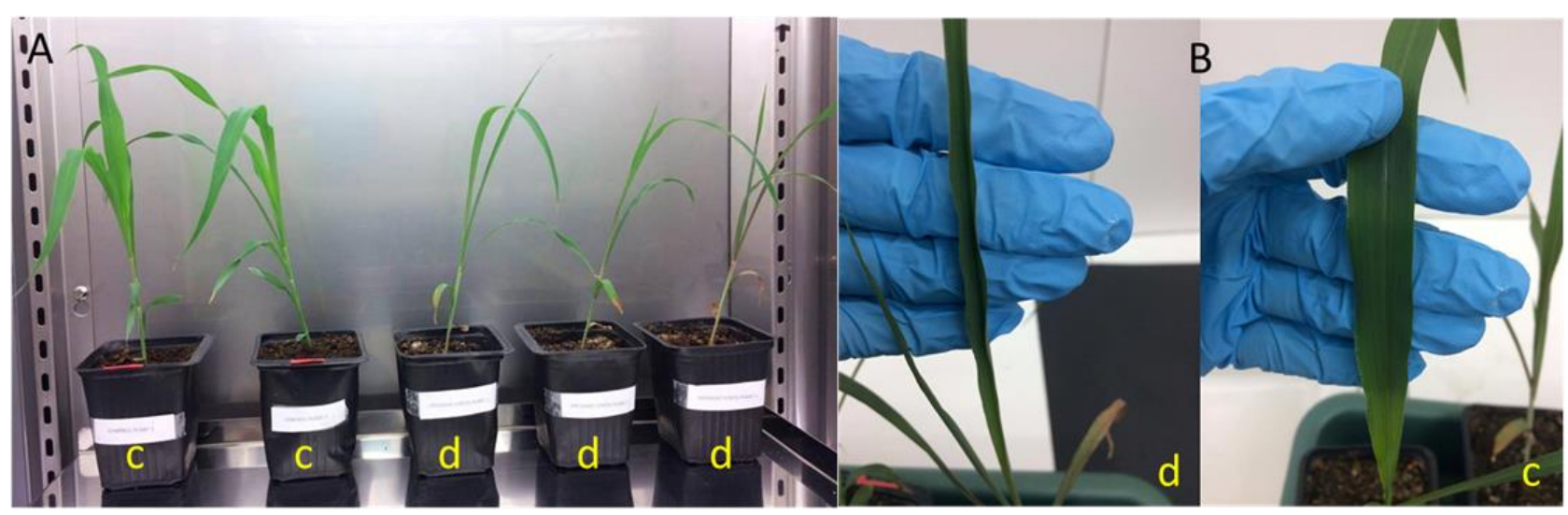

Şekil 1. On günlük kuraklık stresinin sorgum bitkilerindeki etkisi. (A) Kuraklığa maruz kalmış bitkilerde bitki gelişimi gerilemiş, su kaybını azaltmak için yapraklar dikleşmiş ve yaprak sayısı azalmıştır. (B) Kuraklığa maruz kalmış bitkilerde yaprak alanı küçülmüştür. d: Kuraklık, c: Kontrol.

Figure 1. Effect of 10-day drought stress in sorghum plants. (A) Plant development is retarded, leaves are erected, and leaf numbers are reduced in drought-stressed plants. (B) Leaf area is reduced in drought-stressed plants. d: Drought-stressed plants, c: Control.

hücrelerinde turgor basıncındaki düşüş, enzim aktivitelerindeki bozulma ve enerji miktarındaki düşüşten kaynaklanabilir. Kuraklık stresine maruz kalmış bitkilerde benzer belirtiler daha önce yapılmış çalışmalarda da rapor edilmiştir (Bosabalidis ve Kofidis 2002; Farooq ve ark. 2010; Taiz ve Zeiger 2010).

SULTR genlerinin fonksiyonlarını araştırmak için, Akbudak ve ark. (2018) tarafından tanımlanmış dokuz adet SbSULTR geninin ifadesi 10 gün kuraklığa maruz bırakılmış sorgum bitkilerinde RT-qPCR kullanılarak incelenmiştir. Bu genlerden SULTR1;3，SULTR2;2，SULTR3;1，SULTR3;3，SULTR4'ün yapraklarda ifadesinin arttı̆ 1 (up-regulated), SULTR2;1, SULTR3;2, SULTR3;4'ün ifadesinin azaldığı (down-regulated), SULTR3;5' in ifadesinde herhangi bir değişiklik olmadığ 1 tespit edilmiştir (Şekil 2A). Köklerde ise SULTR2;1, SULTR2;2, SULTR3;1, SULTR3;3, SULTR3;5 ve SULTR4 genlerinin ifadesinin arttı̆g1, SULTR1;3 ve SULTR3;4 genlerinin ifadesinin azaldığı SULTR3;2'nin ifadesinin kontrol bitkilerine kıyasla değişmediği görülmüştür (Şekil 2B). SULTR2 grubuna ait genlerin ifadelerinin köklerdeki ifade seviyelerinin yapraklardaki ifade seviyelerinden $2-3$ kat daha fazla olması kuraklık stresi altında köklerden sürgünlere sülfat taşınması için köklerde SULTR2 grubu proteinlere daha fazla ihtiyaç duyulduğunu göstermektedir.

SULTR3 grubuna ait genlerin abiyotik streslerde ifadesinin arttığı çeşitli çalışmalarla gösterilmiştir. Gallardo ve ark. (2014) Medicago truncatula da yaptıkları çalışmada SULTR3;1 ve SULTR3;5' in sirasıyla tuzluluk ve kuraklık stresi altında bitki köklerinde yüksek miktarda ifade edildiğini bildirmişlerdir. Tombuloglu ve ark. (2017) ise Brachypodium ditachyon'da BdSULTR3;1 geninin ifadesinin kuraklık stresi altında arttığını göstermişlerdir. Cao ve ark. (2013) Arabidopsis'te AtSULTR3; 1'in ABA'nın hücre tarafindan sentezlenmesinde görev alan sisteine sülfat sağlayarak bitkilerin çevresel streslerle mücadelesinde görev aldığını bildirmişlerdir. Bu çalışmalarla paralel olarak bizim çalışmamızda da incelenen SULTR3 grubuna dahil beş gen içerisinde en fazla aktive olan genin SbSULTR3; 1 olduğu, köklerde ve yapraklarda ifadesinin diğer SULTR3 grubu genlere göre yaklaşı $2-3$ kat daha fazla olduğu görülmüştür.

Tüm SbSULTR genleri içerisinde kuraklık stresi altında ifadesi en yüksek genin kontrol genine göre yapraklarda 7 kat daha fazla ifade edilen SULTR4 geni olduğu görülmektedir. SULTR4 geni köklerde de kontrol bitkilerine göre yaklaşık 2 kat daha fazla ifade edilmektedir. SULTR4 geninin yapraklardaki ifadesindeki bu dramatik artış kuraklık stresi altında bitkinin bu stresle mücadelede etmesini sağlayan $\mathrm{ABA}$ ve glutatyon gibi kükürt içeren bileşiklere ihtiyacının artmış olabileceğine, bu nedenle SULTR4 genleri yardımıyla vakuollerden sitoplazmaya yüksek miktarda sülfat taşındığına işaret etmektedir. Ayrıca gen ifade verileri, SULTR geninin dâhil olduğu grubun ve doku tipinin SULTR genlerinin ifade seviyelerini etkilediğini de ortaya çıkarmıştır. Sonuç olarak; sorgum bitkisinde kuraklık stres koşulları altında, SULTR genlerinin mücadelede aktif olarak rol aldığı görülmüştür. 


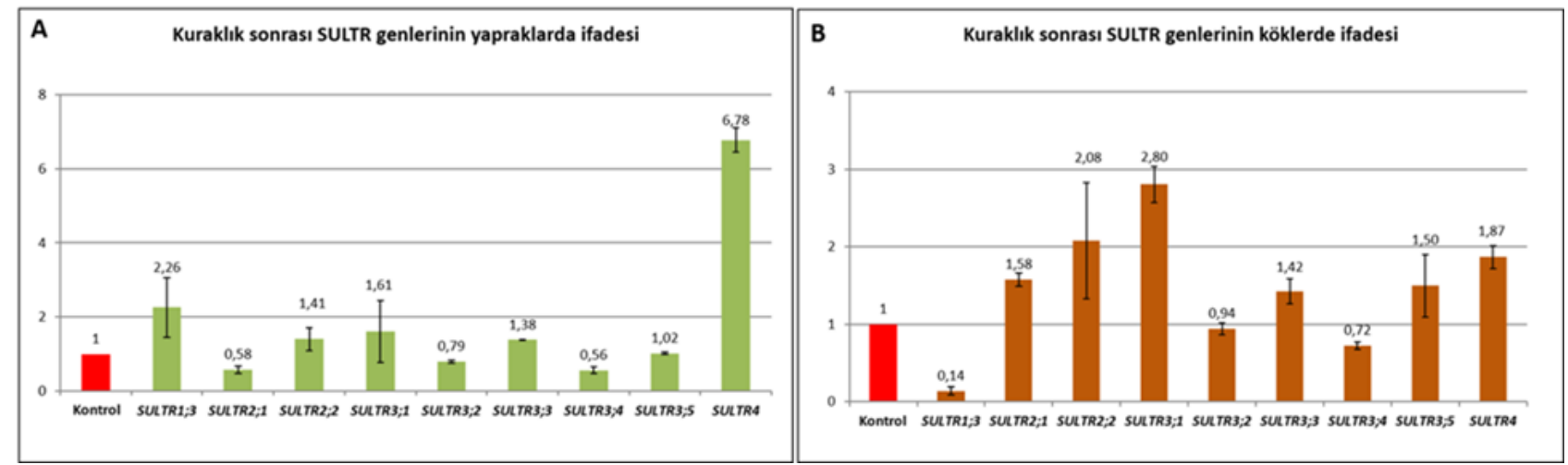

Şekil 2. 10 gün kuraklık stresi uygulanmış sorgum bitkilerinde SULTR genlerinin yapraklarda (A) ve köklerde (B) ifade analizi. SULTR ifade verileri $S b P P 2 A$ geni ifadesine göre normalize edilmiştir. Hata çubukları standart sapmayı göstermektedir.

Figure 2. The expression analyses of sorghum SULTR (SBSULTR) genes in response to 10-day drought exposure in leaves (A) and roots (B). The expressions were normalized using SbPP2A gene. Error bar shows the standard deviation in relative expressions of three replicates.

\section{Teşekkür} ederim.

Teknik yardımlarından dolayı Kübra Kontbay’a teşekkür

\section{Kaynaklar}

Akbudak M, Filiz E, Kontbay K (2018) Genome-wide identification and cadmium induced expression profiling of sulfate transporter (SULTR) genes in sorghum (Sorghum bicolor L.) Biometals 31: 91-105 doi: 10.1007/s10534-017-0071-5.

Boaretto L, Carvalho G, Borgo L, Creste S, Landell M, Mazzafera P, Azevedo R (2014) Water stress reveals differential antioxidant responses of tolerant and non-tolerant sugarcane genotypes Plant Physiology and Biochemistry 74: 165-175 doi: 10.1016/j.plaphy.2013.11.016.

Bosabalidis A, Kofidis G (2002) Comparative effects of drought stress on leaf anatomy of two olive cultivars Plant Science 163: 375-379 doi: 10.1016/s0168-9452(02)00135-8.

Buchner P, Takahashi H, Hawkesford M (2004) Plant sulphate transporters: co-ordination of uptake, intracellular and longdistance transport Journal of Experimental Botany 55: 1765-1773 doi: $10.1093 / \mathrm{jxb} / \mathrm{erh} 206$.

Cao M, Wang Z, Wirtz M, Hell R, Oliver D, Xiang C (2013) SULTR3;1 is a chloroplast-localized sulfate transporter in Arabidopsis thaliana Plant Journal 73: 607-616 doi: 10.1111/tpj.12059.

Capaldi F, Gratao P, Reis A, Lima L, Azevedo R (2015) Sulfur Metabolism and Stress Defense Responses in Plants Tropical Plant Biology 8: 60-73 doi: 10.1007/s12042-015-9152-1.

Choudhury S, Panda P, Sahoo L, Panda SK (2013) Reactive oxygen species signaling in plants under abiotic stress Plant Signal Behav 8: e23681 doi: 10.4161/psb.23681.

Davidian J, Kopriva S (2010) Regulation of Sulfate Uptake and Assimilation-the Same or Not the Same? Molecular Plant 3: 314-325 doi: 10.1093/mp/ssq001.

Ernst L, Goodger JQ, Alvarez S, Marsh EL, Berla B, Lockhart E, Jung J, Li P, Bohnert HJ, Schachtman DP (2010) Sulphate as a xylemborne chemical signal precedes the expression of ABA biosynthetic genes in maize roots Journal of Experimental Botany 61: 3395-3405 doi: 10.1093/jxb/erq160.

Farooq M, Kobayashi N, Ito O, Wahid A, Serraj R (2010) Broader leaves result in better performance of indica rice under drought stress Journal of Plant Physiology 167: 1066-1075 doi: 10.1016/j.jplph.2010.03.003.

Fatma M, Khan MIR, Masood A, Khan NA (2013) Coordinate changes in assimilatory sulfate reduction are correlated to salt tolerance: Involvement of phytohormones Annual Review \& Research in Biology. 3. 267-295.
Gallardo K, Courty P, Le Signor C, Wipf D, Vernoud V (2014) Sulfate transporters in the plant's response to drought and salinity: regulation and possible functions Frontiers in Plant Science 5 doi: 10.3389/fpls.2014.00580.

Kopriva S (2006) Regulation of sulfate assimilation in Arabidopsis and beyond. Ann Bot 97: 479-495 doi.org/10.1093/aob/mcl006.

Livak K, Schmittgen T (2001) Analysis of relative gene expression data using real-time quantitative PCR and the 2(T)(-Delta Delta C) method Methods 25: 402-408 doi: 10.1006/meth.2001.1262.

Maruyama-Nakashita A, Nakamura Y, Watanabe-Takahashi A, Yamaya T, Takahashi H (2004) Induction of SULTR1;1 sulfate transporter in Arabidopsis roots involves protein phosphorylation/dephosphorylation circuit for transcriptional regulation Plant and Cell Physiology 45: 340-345 doi: $10.1093 / \mathrm{pcp} / \mathrm{pch} 029$.

Maruyama-Nakashita A, Nakamura Y, Watanabe-Takahashi A, Inoue E, Yamaya T, Takahashi H (2005) Identification of a novel cisacting element conferring sulfur deficiency response in Arabidopsis roots Plant Journal 42: $305-314$ doi: $10.1111 / \mathrm{j} .1365-$ 313X.2005.02363.x.

Noctor G (2006) Metabolic signalling in defence and stress: the central roles of soluble redox couples Plant Cell and Environment 29: 409425 doi: 10.1111/j.1365-3040.2005.01476.x.

Peleg Z, Blumwald E (2011) Hormone balance and abiotic stress tolerance in crop plants Current Opinion in Plant Biology 14: 290-295 doi: 10.1016/j.pbi.2011.02.001.

Reddy PS, Reddy DS, Sivasakthi K, Bhatnagar-Mathur P, Vadez V, Sharma KK (2016) Evaluation of Sorghum [Sorghum bicolor (L.)] reference genes in various tissues and under abiotic stress conditions for quantitative real-time PCR data normalization. Front Plant Sci 7 doi.org/10.3389/fpls.2016.00529.

Taiz L, Zeiger E (2010) Plant Physiology. 5th Edition, Sinauer Associates, Inc., Sunderland.

Takahashi H, Buchner P, Yoshimoto N, Hawkesford M, Shiu S (2012) Evolutionary relationships and functional diversity of plant sulfate transporters Frontiers in Plant Science 2 doi: 10.3389/fpls.2011.00119.

Tombuloglu H, Filiz E, Aydin M, Koc I (2017) Genome-wide identification and expression analysis of sulphate transporter (SULTR) genes under sulfur deficiency in Brachypodium distachyon Journal of Plant Biochemistry and Biotechnology 26: 263-273 doi: 10.1007/s13562-016-0388-0.

Wilkinson S, Davies W (2002) ABA-based chemical signalling: the coordination of responses to stress in plants Plant Cell and Environment 25: 195-210 doi: 10.1046/j.0016-8025.2001.00824.x. 